\title{
Clinical efficacy of tigecycline used as monotherapy or in combination regimens for complicated infections with documented involvement of multiresistant bacteria
}

\author{
W. R. Heizmann · P.-A. Löschmann · C. Eckmann • \\ C. von Eiff $\cdot$ K.-F. Bodmann $\cdot$ C. Petrik
}

Received: 18 June 2014 / Accepted: 8 October 2014 / Published online: 4 November 2014

(C) The Author(s) 2014. This article is published with open access at Springerlink.com

\begin{abstract}
Introduction Tigecycline is an established treatment option for infections with multiresistant bacteria (MRB). It retains activity against many strains with limited susceptibility to other antibiotics. Efficacy and safety of tigecycline as monotherapy or in combination regimens were investigated in a prospective noninterventional study involving 1,025 severely ill patients in clinical routine at 137 German hospitals.

Materials and methods Data on the full population have been published; our present analysis focuses on infections caused by MRB. The study population included patients with complicated infections, high disease severity (APACHE II > 15: $65 \%$ ) and high MRB prevalence. Most patients had comorbidities, including cardiovascular disease, renal insufficiency, and/or diabetes mellitus. Treatment success was defined as cure/improvement without requirement of further antibiotic therapy.

Results Pathogens isolated from 215 evaluable patients with documented MRB infections included 132 methicillin-resistant Staphylococcus aureus (MRSA), 42 vancomycin-resistant Enterococci (VRE) and 67 Gram-negative extended beta-lactamase (ESBL) producers. Of the MRB
\end{abstract}

W. R. Heizmann $(\bowtie)$

Orgamed Laborsysteme GmbH, Maria-Schmid-Str. 14b, 94086 Bad Griesbach, Germany

e-mail: wrheizmann@aol.com; orgamed.consulting@aol.com

P.-A. Löschmann · C. von Eiff · C. Petrik

Pfizer Pharma GmbH, Linkstraße 10, 10785 Berlin, Germany

C. Eckmann

Klinikum Peine, Virchowstraße 8 h, 31221 Peine, Germany

K.-F. Bodmann

Klinikum Barnim GmbH, Rudolf-Breitscheid-Straße 36,

16225 Eberswalde, Germany subpopulation, 140 patients received tigecycline monotherapy, 75 were treated with combination regimens. High overall clinical success rates were recorded for MRB infections treated with tigecycline alone $(94 \%)$ or in combinations $(88 \%)$; in detail intraabdominal infections (monotherapy: $90 \%$; combinations: $93 \%$ ), skin/soft tissue infections $(93 ; 100 \%)$, community-acquired pneumonia $(100 ; 100 \%)$, hospital-acquired pneumonia $(94,7 ; 72,7 \%)$, diabetic foot infections $(89 ; 33 \%)$, blood stream infections $(100 ; 100 \%)$ and multiple-site infections $(92 ; 71 \%)$.

Conclusions Tigecycline achieved high clinical success rates in patients with documented infections involving MRB strains despite high disease severity. These results add to the evidence indicating that tigecycline is a valuable therapeutic option for complicated infections in severely ill patients with a high likelihood of multidrug-resistant pathogen involvement.

Keywords Tigecycline - Non-interventional study · Multiresistant pathogens $\cdot$ Methicillin-resistant Staphylococcus aureus · Extended-spectrum betalactamase $\cdot$ Vancomycin-resistant enterococci

\section{Purpose}

Tigecycline is a glycylcycline antibiotic with a broad spectrum of antimicrobial activity covering bacteria with resistance against multiple antibiotics (MRB) such as vancomycin-resistant enterococci (VRE), methicillin-resistant Staphylococcus aureus (MRSA), extended-spectrum beta-lactamase producing Enterobacteriaceae (ESBL) and strains of the Acinetobacter baumannii group [1-4].

In the US [5] and Europe [6], tigecycline is approved for the treatment of complicated intraabdominal infections 
(cIAI) and complicated skin and skin tissue infections (cSSTI). In the US, tigecycline is also indicated for community-acquired bacterial pneumonia.

The patient population in the two pivotal phase III studies on tigecycline in cIAI had a relatively low mean initial APACHE II score of 6.3, as patients with APACHE II scores $>30$ were excluded [7]. The number of severely ill patients was limited in both phase III cSSTI trials as well [8]. Thus, published data from prospective (comparative) trials on tigecycline used in higher risk patients with complicated, pre-treated infections and high risk of drug-resistant pathogens are limited.

Most data on tigecycline in severely ill patients are derived from retrospective analyses or studies focused on identified pathogens rather than clinical syndromes. Bassetti et al. [9] reported on a single-center prospective observational study of tigecycline in severely ill patients with various complicated infections. The authors found high response rates for peritonitis, cSSTI and blood stream infections despite unfavorable patient risk profiles (mean APACHE II score 21; high prevalence of severe comorbidities).

In recent years, Enterobacteriaceae developed a range of antimicrobial resistances that reduce therapeutic choices to a very limited set of active antibiotics. The spread of ESBL-producers and bacterial strains expressing carbapenemases is causing much concern on the future options of effective antibacterial therapy in hospitals [10]. In addition, in the Gram-positive spectrum of pathogens, MRSA remains a threat in cSSTI [11], DFI [12], and hospitalacquired pneumonia (HAP) [13], while VRE are commonly implicated in severe cIAI and blood stream infections (BSI) [14]. Because these pathogens are commonly found in infections taking a severe course, tigecycline becomes an increasingly important treatment option for a broad range of severe infections, particularly as empirical therapy in patients at risk for MRB.

Consequently, there is a need for additional clinical data to evaluate the usefulness of tigecycline, thereby providing additional evidence for the rational and safe use of this antibiotic.

This sub-analysis of a prospective, non-interventional study investigated the efficacy and safety of tigecycline used alone or in combination in the real-life hospital setting in Germany. Results obtained in the total patient population have been published before [15]. Here, we present data on patients suffering from infections with documented involvement of bacteria exhibiting multidrugresistant phenotypes. We characterized the subpopulation treated with tigecycline for these infections in various indications and determined treatment outcomes associated with tigecycline used alone or in combination with other antimicrobials.

\section{Methods}

Details on the methodology of the non-interventional parent study have been published before [15]. Briefly, hospital-based physicians prospectively documented data on patients treated with tigecycline for cIAI, cSSTI or other severe infections according to local routine practice. The population observed in this study included severely ill patients with previous/failed antimicrobial treatment and/ or involvement of drug-resistant pathogens. Infections were classified as hospital vs. community acquired depending on the first manifestation of the infection after or before $48 \mathrm{~h}$ of hospitalization. The study protocol involved an initial intravenous dose of $100 \mathrm{mg}$ of tigecycline $\left(\right.$ Tygacil $^{\circledR}$; Pfizer Pharma GmbH, Berlin, Germany), followed by $50 \mathrm{mg}$ tigecycline every $12 \mathrm{~h}$, as recommended in the product label.

The present analyses include only those patients who had infections with documented involvement of multiresistant bacteria (VRE, MRSA, ESBL-producers) and evaluable treatment outcomes. ESBL-production was detected by combination disk testing with clavulanic acid or VITEK II, methicillin resistance by testing cefoxitin and VRE by E-test, breakpoint agars, or VITEK II according to the protocol of the local microbiology laboratory.

Table 1 Patient demographics, comorbidities and severity scores at baseline

\begin{tabular}{|c|c|c|}
\hline Patient demographics & Total population & Patients with MRB \\
\hline Number of patients, $n$ & 1,025 & 256 \\
\hline \multicolumn{3}{|c|}{ Demographic characteristics } \\
\hline Male, $\%(n)$ & $62.8 \%(642)$ & $64.8 \%(166)$ \\
\hline $\begin{array}{l}\text { Age, mean } \\
\text { years } \pm \mathrm{SD} \\
(\text { range })\end{array}$ & $64.4 \pm 13.7(18-94)$ & $66.5 \pm 12.0(19-88)$ \\
\hline \multicolumn{3}{|l|}{ Clinical characteristics } \\
\hline $\begin{array}{l}\text { BMI, mean, } \\
\mathrm{kg} / \mathrm{m}^{2} \pm \mathrm{SD} \\
\text { (range) }\end{array}$ & $27.7 \pm 6.5(14-90)$ & $28.4 \pm 7.0(14.6-58.8)$ \\
\hline $\begin{array}{l}\text { Treatment on } \\
\text { ICU, \% (n) }\end{array}$ & $53.2 \%(545)$ & $41.8 \%(107)$ \\
\hline $\begin{array}{l}\text { History of prior } \\
\text { antibiotics, \% (n) }\end{array}$ & $84.5 \%(864)$ & $83.2 \%(213)$ \\
\hline Comorbidity, \% (n) & $96.5 \%(989)$ & $96.1 \%(246)$ \\
\hline $\begin{array}{l}\text { APACHE II score } \\
>15, \%(n)\end{array}$ & $64.9 \%(607)$ & $68.4 \%(162)$ \\
\hline $\begin{array}{l}\text { APACHE II score, } \\
\text { mean (median) }\end{array}$ & $18.8(18.0)$ & $19.4(19.0)$ \\
\hline $\begin{array}{l}\text { Patients with } \\
\text { treatment on } \\
\text { ICU }\end{array}$ & $20.0(20.0)$ & $21.4(21.0)$ \\
\hline $\begin{array}{l}\text { Patients with } \\
\text { treatment } \\
\text { outside ICU }\end{array}$ & $17.3(17.0)$ & $17.9(18.0)$ \\
\hline
\end{tabular}


Table 2 Distribution of multiresistant bacteria by site of infection (patients with evaluable treatment outcome; $n=215$ )

Patients could have more than one MRB

\begin{tabular}{lllll}
\hline Drug-resistance phenotype, $\%(n)$ & \multicolumn{4}{l}{ Patients with documented MRB infection } \\
\cline { 2 - 5 } & Any MRB & VRE & MRSA & ESBL \\
\hline Total MRB population & $100 \%(215)$ & $19.5 \%(42)$ & $61.4 \%(132)$ & $31.2 \%(67)$ \\
Intraabdominal infection (cIAI) & $32.6 \%(70)$ & $38.6 \%(27)$ & $27.1 \%(19)$ & $50.0 \%(35)$ \\
Skin and soft tissue infection (cSSTI) & $25.6 \%(55)$ & $5.5 \%(3)$ & $90.9 \%(50)$ & $7.3 \%(4)$ \\
Diabetic foot infection (DFI) & $14.0 \%(30)$ & $-(0)$ & $100.0 \%(30)$ & $10.0 \%(3)$ \\
Community-acquired pneumonia (CAP) & $6.0 \%(13)$ & $7.7 \%(1)$ & $84.6 \%(11)$ & $38.5 \%(5)$ \\
Hospital-acquired pneumonia (HAP) & $14.0 \%(30)$ & $-(0)$ & $70.0 \%(21)$ & $30.0 \%(9)$ \\
Blood stream infection (BSI) & $10.2 \%(22)$ & $18.2 \%(4)$ & $68.2 \%(15)$ & $36.4 \%(8)$ \\
Multiple-site infection (MSI) & $12.6 \%(27)$ & $14.8 \%(4)$ & $63.0 \%(17)$ & $44.4 \%(12)$ \\
\hline
\end{tabular}

The investigators rated the therapeutic outcome as cure, improvement with no further need for antibiotic treatment, failure to respond or not evaluable. Rating the outcome as cure required full resolution of symptoms of infection, whereas improvement was defined as significant improvement of symptoms but without complete resolution of infection. Outcome was rated 1-3 days after the end of tigecycline therapy or at hospital discharge. Treatment success was defined as cure or improvement with no further need for antibiotic treatment.

\section{Results}

Patient demographic and clinical characteristics

1025 patients were treated with tigecycline in 137 German hospitals. Of these patients, 256 had infections due to multiresistant bacteria. Demographic and clinical characteristics of evaluable patients are presented in Table 1.

A large proportion of this predominantly elderly MRB subpopulation (mean age: 66.5 years) was treated on intensive care units $(41.8 \%)$. The median APACHE II score was 21.5. Virtually all patients had at least one comorbidity. Most patients $(83.2 \%)$ had received prior therapy with other antibiotics.

\section{Pathogens and sites of infection}

MRSA was the most commonly isolated multiresistant pathogen (61.4\% of the patients), followed by ESBL-producers $(31.2 \%)$ and VRE (19.5\%) (Table 2). Most patients with MRB had cIAI (32.6\%) or cSSTI (25.6\%), followed by other severe infections, such as hospital- or communityacquired pneumonia $(20.0 \%)$, diabetic foot infections (DFI; $14.0 \%$ ), blood stream infections BSI $(10.2 \%)$ or multiple-site infections (MSI; $12.6 \%$ ). MRSA was the predominant pathogen in patients with cSSTI (90.9\%), CAP $(84.6 \%)$, HAP $(70.0 \%)$, DFI $(100 \%)$ and BSI $(68.2 \%)$. ESBL-producers were the most common MRB in patients with cIAI $(50.0 \%)$ and VRE were the second most pathogens isolated in patients with cIAI $(38.6 \%)$.

Mode and duration of therapy

The great majority of patients (initial dose $\geq 95.7 \%$; maintenance doses $\geq 91.9 \%$ ) received tigecycline at the recommended dosage ${ }^{1}$ as monotherapy $(65.1 \%)$ or in combination regimens $(34.9 \%$ ) (Table 3 ). Combination therapy was most common in cIAI $(40.0 \%)$. Most patients treated with combination regimens received ceftazidime, a carbapenem, a fluoroquinolone or metronidazole in addition to tigecycline (Table 4).

Median treatment duration was 8 days for BSI (range 4-17), 9 days for HAP (5-17), 10 days for IAI (2-40) and CAP (7-15), 11 days for SSTI (4-33) and DFI (4-42), and 12 days for MSI (5-42).

\section{Clinical outcome}

The clinical outcome of tigecycline treatment per patient subgroup is shown in Tables 5 and 6. Treatment success rates were generally in the range of $80-100 \%$ regardless of the type of involved MRB.

Complicated IAI were successfully treated in 91.4$96.3 \%$. HAP success rates were somewhat higher with MRSA (94.7\%) than with ESBL-producers (88.8\%), but the patient number was low in the latter subgroup. Tigecycline was effective in most DFI $(83.3 \%)$ which were almost exclusively caused by MRSA. In cSSTI, again dominated by MRSA, an overall success rate of $94.5 \%$ was observed. The treatment success rate was $100 \%$ for BSI and CAP in all MRB subgroups. Patients with multiple-site MRB infections had a success rate of $81.5 \%$.

\footnotetext{
${ }^{1}$ Initial dose was not reported in 1 patient; maintenance dose was not reported in 10 patients. The following divergent dosage regimens were reported: initial dose: $50 \mathrm{mg}$ (7 patients), $70 \mathrm{mg}(1), 2 \mathrm{x}$ $100 \mathrm{mg}$ (1), not specified (1); maintenance doses: $25 \mathrm{mg}$ twice daily (1); $25 \mathrm{mg}$ twice weekly (1); $50 \mathrm{mg}$ once daily (5); $100 \mathrm{mg}$ once daily (1) $100 \mathrm{mg}$ twice daily (1), $150 \mathrm{mg}$ twice daily (1); not specified (1).
} 
Table 3 Mode of therapy in patients with multiresistant pathogens by site of infection (patients with evaluable treatment outcome; $n=215)$

\begin{tabular}{lll}
\hline Proportion of patients, \% $(n)$ & Monotherapy & Combination therapy \\
\hline Total MRB population & $65.1 \%(140)$ & $34.9 \%(75)$ \\
Intraabdominal infection (cIAI) & $28.6 \%(40)$ & $40.0 \%(30)$ \\
$\begin{array}{l}\text { Skin and soft tissue infection } \\
\quad(\mathrm{cSSTI})\end{array}$ & $31.4 \%(44)$ & $14.7 \%(11)$ \\
$\quad \begin{array}{l}\text { Diabetic foot infection (DFI) } \\
\text { Community-acquired }\end{array}$ & $19.3 \%(27)$ & $4.0 \%(3)$ \\
$\quad$ pneumonia (CAP) & $8.6 \%(12)$ & $1.3 \%(1)$ \\
Hospital-acquired pneumonia & $13.6 \%(19)$ & $14.7 \%(11)$ \\
$\quad($ HAP) & & \\
Blood stream infection (BSI) & $12.9 \%(18)$ & $5.3 \%(4)$ \\
Multiple-site infection (MSI) & $9.3 \%(13)$ & $18.7 \%(14)$ \\
\hline
\end{tabular}

Patients could have more than one MRB; 2 patients with HAP were diagnosed with BSI as well, these were not categorized as MSI because the lung infection was regarded as the focus of BSI

Table 4 Antibiotics most commonly administered in combination with tigecycline (patients with evaluable treatment outcome; $n=215$ )

\begin{tabular}{ll}
\hline Antibiotic agent & Patients, \% (n) \\
\hline All agents & $34.9 \%(75)$ \\
Ceftazidime & $11.2 \%(24)$ \\
Carbapenem (meropenem, imipenem) & $5.6 \%(12)$ \\
Fluoroquinolone (ciprofloxacin, levofloxacin) & $4.7 \%(10)$ \\
Metronidazole & $3.7 \%(8)$ \\
Piperacillin ( \pm tazobactam) & $1.9 \%(4)$ \\
Vancomycin & $1.4 \%(3)$ \\
Cefepime & $1.4 \%(3)$ \\
Sulbactam & $0.9 \%(2)$ \\
Clindamycin & $0.9 \%(2)$ \\
Gentamicin & $0.9 \%(2)$ \\
Others & $2.3 \%(5)$ \\
\hline
\end{tabular}

Regarding treatment modality, the success rate was $93.6 \%$ for monotherapy, with rates ranging from 89.9 to $100 \%$ for the different types of infection and drug-resistant bacteria (Fig. 1a; Table 6).

Using combination therapies, $88.0 \%$ of the patients were successfully treated, with rates ranging from $71.4 \%$ to $100 \%$ for all types of infections. The rate was lower in DFI $(33.3 \%)$, albeit based on only 3 patients in this subgroup (Fig. 1b; Table 6).

\section{Discussion}

The patients analyzed in this subpopulation with MRB infections were treated with tigecycline in routine settings in German hospitals. They suffered from complicated IAI,

Table 6 Treatment success rates (cure + improvement) in patients with multiresistant pathogens by mode of therapy (patients with evaluable outcome; $n=215$ )

\begin{tabular}{lll}
\hline Treatment success $\%(n / N)$ & Monotherapy & Combination therapy \\
\hline $\begin{array}{l}\text { Total MRB population } \\
\text { Intraabdominal infection } \\
\quad(\mathrm{sIAI})\end{array}$ & $93.6 \%(131 / 140)$ & $88.0 \%(66 / 75)$ \\
$\begin{array}{l}\text { Skin and soft tissue } \\
\text { infection (cSSTI) }\end{array}$ & $93.2 \%(41 / 44)$ & $100 \%(11 / 11)$ \\
$\begin{array}{l}\text { Diabetic foot infection } \\
\quad \text { DFI) }\end{array}$ & $88.9 \%(24 / 27)$ & $33.3 \%(1 / 3)$ \\
$\begin{array}{l}\text { Community-acquired } \\
\text { pneumonia (CAP) }\end{array}$ & $100 \%(12 / 12)$ & $100 \%(1 / 1)$ \\
$\begin{array}{l}\text { Hospital-acquired } \\
\text { pneumonia (HAP) }\end{array}$ & $94.7 \%(18 / 19)$ & $72.7 \%(8 / 11)$ \\
$\begin{array}{l}\text { Blood stream infection } \\
\quad(B S I)\end{array}$ & $100 \%(18 / 18)$ & $100 \%(4 / 4)$ \\
$\begin{array}{l}\text { Multiple-site infection } \\
\text { (MSI) }\end{array}$ & $92.3 \%(12 / 13)$ & $71.4 \%(10 / 14)$ \\
\hline
\end{tabular}

Table 5 Treatment success rates (cure + improvement) in patients with multiresistant pathogens by drug-resistance phenotype (patients with evaluable treatment outcome; $n=215$ )

\begin{tabular}{lllll}
\hline Treatment success $\%(n / N)$ & \multicolumn{2}{l}{ Patients with documented MRB infection } & & MRSA \\
\cline { 2 - 5 } & Any MRB & VRE & $90.2 \%(120 / 132)$ & ESBL \\
\hline Total MRB population & $91.6 \%(197 / 215)$ & $97.6 \%(41 / 42)$ & $91.0 \%(61 / 67)$ \\
Intraabdominal infection (cIAI) & $91.4 \%(64 / 70)$ & $96.3 \%(26 / 27)$ & $89.5 \%(17 / 19)$ & $91.4 \%(32 / 35)$ \\
Skin and soft tissue infection (cSSTI) & $94.5 \%(52 / 55)$ & $100 \%(3 / 3)$ & $94.0 \%(47 / 50)$ & $100 \%(4 / 4)$ \\
Diabetic foot infection (DFI) & $83.3 \%(25 / 30)$ & $-(0 / 0)$ & $83.3 \%(25 / 30)$ & $66.6 \%(2 / 3)$ \\
Community-acquired pneumonia (CAP) & $100 \%(13 / 13)$ & $100 \%(1 / 1)$ & $100 \%(11 / 11)$ & $100 \%(5 / 5)$ \\
Hospital-acquired pneumonia (HAP) & $86.7 \%(26 / 30)$ & $-(0 / 0)$ & $85.7 \%(18 / 21)$ & $88.8 \%(8 / 9)$ \\
Blood stream infection (BSI) & $100 \%(22 / 22)$ & $100 \%(4 / 4)$ & $100 \%(15 / 15)$ & $100 \%(8 / 8)$ \\
Multiple-site infection (MSI) & $81.5 \%(22 / 27)$ & $100 \%(4 / 4)$ & $76.5 \%(13 / 17)$ & $83.3 \%(10 / 12)$ \\
\hline
\end{tabular}

Patients could have more than one MRB 

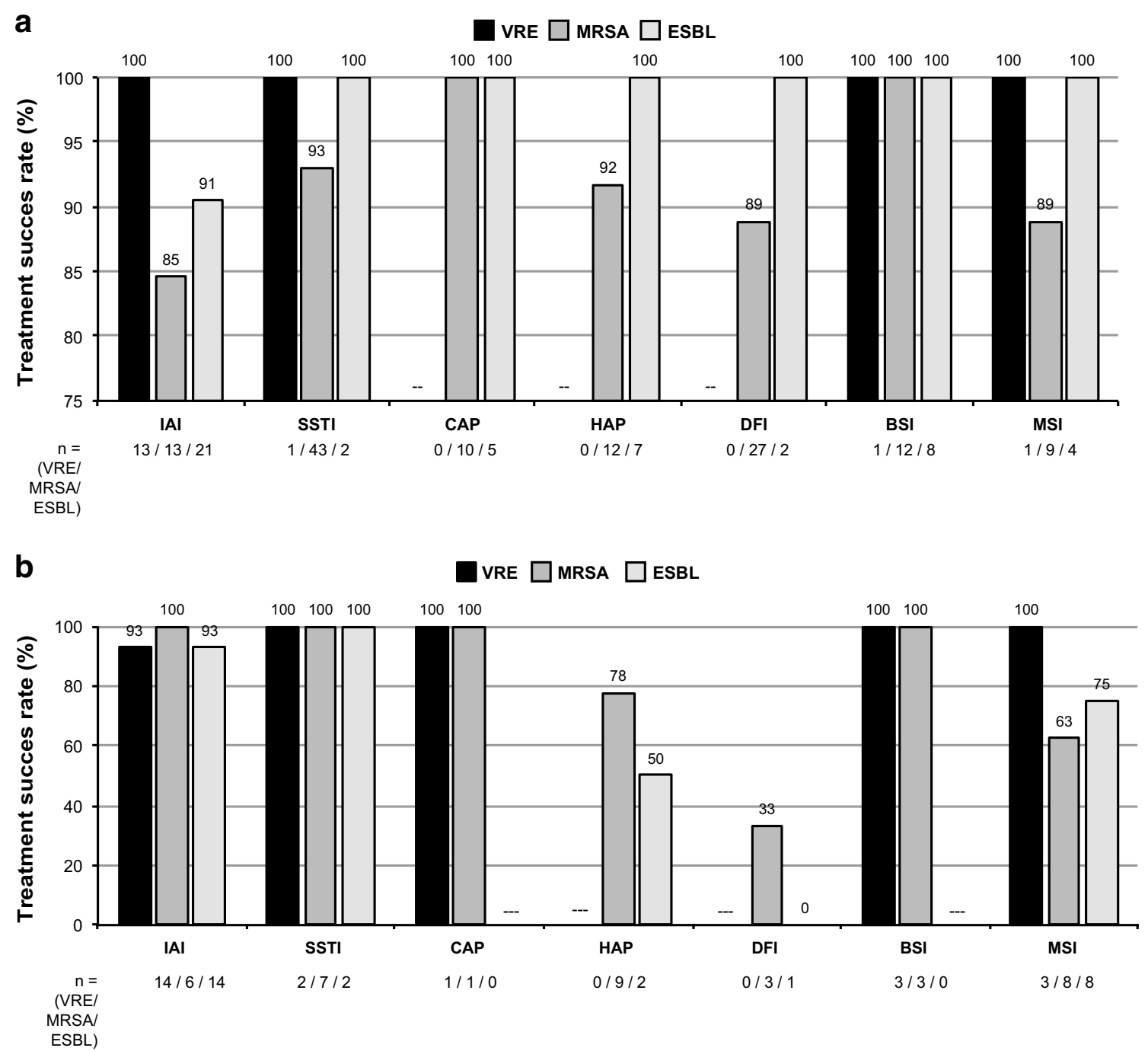

Fig. 1 Treatment success rates (cure + improvement) in patients with multiresistant pathogens a Monotherapy, b combination therapy. IAI intraabdominal infection, $B S I$ blood stream infection, $C A P$

SSTI, and/or other severe infections involving multiresistant bacteria.

Rates of clinical cure or improvement were high in this subpopulation. A total of $91.6 \%$ of patients with MRB infections were successfully treated, $93.6 \%$ with monotherapy and $88.0 \%$ with tigecycline combinations.

Success rates for monotherapy were consistently higher than $90 \%$ for all multiresistant pathogens and higher than $80 \%$ for all disease types; rates were particularly high in BSI $(100 \%)$, CAP $(100 \%)$ and cSSTI $(95 \%)$.

The success rates tended to be somewhat lower in combination therapies ( 88.0 vs. $93.6 \%$ with monotherapy), mostly due to the response rates in patients with MSI (71.4\%), or HAP $(72.3 \%)$. This divergence may have been caused (1) by a higher likelihood of combination therapies being used in patients with higher disease severity, (2) the community-acquired pneumonia, DFI diabetic foot infection, $H A P$ hospital-acquired pneumonia, MSI multiple-site infection, SSTI skin and soft tissue infection

choice of the combination drug, (3) random effects due to small patient numbers, and (4) the likelihood of higher morbidity in patients with infection at multiple sites of infection.

Conversely, the treatment success rate of MRB nosocomial pneumonia was $94.7 \%$ in patients receiving tigecycline monotherapy at standard dosage. This is a reassuringly high rate in the light of data obtained in the phase III HAP study of tigecycline versus imipenem that failed to confirm the non-inferiority of tigecycline in the clinically evaluable patient subset. A subsequent phase II study with tigecycline used at higher dosages indicated increased efficacy with a clinical cure rate of $85 \%$ [16]. There are several, at least, theoretical reasons why non-bactericidal antimicrobial agents such as tigecycline are effective in severe infections [17]. 
The limitations of this study include its non-controlled observational design that may be associated with several biases and uncertainties, and the lack of rigorous criteria of diagnosis and assessment of response. Despite these shortcomings, this analysis of a sizeable sample of patients with severe MRB infections provides evidence of the usefulness of tigecycline in this diverse and difficult-to-treat population.

Non-interventional studies provide insights into the reallife utility of antibiotics beyond the preselected cohorts treated in randomized trials. Despite that patients infected with multiresistant bacteria are not excluded from pivotal trials, they usually do not represent a large proportion of the whole patient population. Observational studies are particularly useful for the evaluation of substances that are used in indications and situations outside the scope covered by pivotal trials, e.g., in patients with high-risk profiles, multiple comorbidities, highly resistant pathogens, extensively pre-treated infections [18].

\section{Conclusions}

Our subpopulation analysis of the prospective tigecycline non-interventional study conducted in routine settings confirmed the efficacy of tigecycline in the treatment of severely ill patients with complicated, mostly pre-treated infections involving multidrug-resistant pathogens. Tigecycline was administered at the recommended dose with few exceptions.

Tigecycline used alone or in combination was highly effective against infections caused by multidrug-resistant Gram-positive and Gram-negative pathogens in patients even with high disease severity.

These results add to the accumulating evidence indicating that tigecycline is a valuable therapeutic option for complicated infections in severely ill patients at high risk of the involvement of multidrug-resistant pathogens.

Acknowledgments The following investigators documented the patients in this study: P. Abel, Universitätsklinikum Greifswald; W. Albert, Kliniken des Main-Taunus-Kreises Hofheim; F. Bach, Evangelisches Krankenhaus Bielefeld; J. Bamberger, Klinikum NürnbergSüd, Nürnberg; A. Biedler, Katholische Kliniken Essen-Nord Essen; U. Bindernagel, Krankenhaus Strausberg; M. Birth, Hanse-Klinikum Stralsund; R. Borgstedt, Evangelisches Krankenhaus-Johannesstift Bielefeld; A. Brackertz, Katholisches Klinikum Mainz; T. Brenig, Neurologisches Rehabilitationszentrum Greifswald; F. Brettner, Krankenhaus Barmherzige Brüder München; H. Burkhard, KMG Klinikum Güstrow; M. De Gols, AK Nord Heidberg Asklepios Klinik Hamburg; T. Derpa, Dominikus-Krankenhaus Düsseldorf; M. Dietlein, Gemeinschaftspraxis Nagel/Dietlein/Hunstiger Augsburg; B. Dummer, Krankenhaus MOL Strausberg; R. Dummler, Krankenhaus Bad Oeynhausen; H. Dürk, Marien-Hospital Hamm; L. Eckholt, Vivantes Klinik am Urban Berlin; E. Egyed, Zentralklinikum Suhl; T. El Ansari, Evangelisches Jung-Stilling-Krankenhaus Siegen; J.
Engel, Universitätsklinikum Giessen; D. Engemann, OberlausitzKliniken gGmbH, Krankenhaus Bischofswerda; F. Ettrich, Klinikum Oberlausitzer Bergland Ebersbach; M. Foedisch, Evangelische Kliniken Bonn; D. Foltys, Johannes-Gutenberg-Universität Mainz; H.G. Fritz, Städtisches Krankenhaus Martha-Maria Halle/Saale; H.G. Gnauk, Klinikum Ernst von Bergmann Potsdam; J. Götz, Klinikum Lippe-Detmold; H. Gratzla, St. Elisabeth-Krankenhaus Gütersloh; M. Groppe, Marienhospital Osnabrück; J. Grosse, Evangelisches Krankenhaus Wesel; M. Hasan, Klinik Löwenstein; M. Haut, AmmerlandKlinik GmbH Westerstede; A. Heininger, Universitätsklinikum Tübingen; J. Henschel, Universitätsklinikum Rostock; C. Hering-Schubert, St. Georg Klinikum Eisenach; K.P. Hermes, Klinikum Bremen-Mitte; R. Hetzer, Deutsches Herzzentrum Berlin; L. Heuer, Klinikum Osnabrück; W. Hilpert, Klinikum Ansbach; O. Hinze, Ruppiner Kliniken Neuruppin; M. Hitz, Krankenhaus St. Joseph-Stift Bremen; R. Höhl, Klinikum Nürnberg- Nord Nürnberg; W. Höhn, Krankenhaus Königin Elisabeth Herzberge Berlin; C. Hönemann, St. Marienhospital Vechta; H.B. Hopf, Asklepios Klinik Langen; A. Höpken, Evangelisches Krankenhaus Oberhausen; P. Hügler, Knappschaftskrankenhaus Bottrop; P. Ihle, Südharz-Krankenhaus Nordhausen; A. Jörres, Charité Campus Virchow-Klinikum Berlin; E. Kammer, Klinikum Stuttgart; M.A. Katz, Evangelisches Krankenhaus Herne; M. Keilen, Klinikum Leverkusen; D. Keller, Borromäus-Hospital Leer; H. Kern, DRK Kliniken Berlin; M. Kiehl, Klinikum Frankfurt/Oder; V. Kimmel, Vivantes Klinikum Prenzlauer Berg Berlin; K. Kogelmann, Klinikum Emden; S. Kopp, Vivantes GmbH Klinikum im Friedrichshain Berlin; A. Kraft, Evangelisches Krankenhaus Oldenburg; O. Krull, Johanniter-Krankenhaus Stendal; M. Kuckhoff, Klinikum Barnim Eberswalde; B. Labinski, Städtische Klinken Mönchengladbach; A. Lange, Oberhavel Kliniken Hennigsdorf; M. Langer, Krankenhaus Köthen; G. Lätzsch, Luisenhospital Aachen; M. Lebender, Asklepios Klinik Harburg Hamburg; M. Leschke, Klinikum Esslingen; H. Liedtke, Krankenhaus St. Elisabeth \& St. Barbara Halle; P. Mailänder, Universitätsklinikum Schleswig-Holstein Lübeck; I. Maiwald, Kreiskrankenhaus Waldbröl; S. Manz, Klinikum Sindelfingen; A. Matuschek, A. Meiser, St. Josef-Hospital Bochum; J. Müller, Marienhospital Stuttgart; T. Müller, Bonhoeffer-Klinikum Neubrandenburg; E. Münch, Fakultät Mannheim, Universität Heidelberg Mannheim; T. Nordmeyer, Sana Kliniken Ostholstein Eutin; M. Paland, Diakoniekrankenhaus Rotenburg; D. Pappert, Ernst von-Bergmann Klinikum Potsdam; D. Paravicini, Städtisches Klinikum Gütersloh; A. Patzelt, Marienhospital Dortmund; L. Pfeiffer, Hufeland Klinikum GmbH Mühlhausen; T. Rabas, KMG Klinikum Wittstock; A. Raible, Universitätsklinik Tübingen; H. Rath, Krankenhaus Werden Essen; G. Rehatschek Kreiskrankenhaus Mechernich; H. Rensing, Universitätsklinikum des Saarlandes Homburg/Saar; M. Reumkens, Katholisches Krankenhaus Süd Essen; V. Rickerts, Klinikum der Johann-Wolfgang-Goethe- Universität Frankfurt/Main; R. Riessen, Medizinische Klinik Tübingen; A. Röhrs, Evangelisches Waldkrankenhaus Spandau Berlin; W. Roth, Universitätsklinikum Mainz; F. Rothfritz-Deutsch, Caritas-Krankenhaus St. Josef Regensburg; K. Röttger, DRK Klinken Westend Berlin; R. Schäfer, Universitätsklinikum Münster; S. Schamrow, Elisabeth-Krankenhaus Essen; U. Schenk, Evangelisches Krankenhaus Unna; A. Scherber, Krankenhaus Püttlingen; S. Schering, Klinikum Fichtelgebirge Marktredwitz; T. Scherke, KMG Klinikum Kyritz; P. Schleufe, Klinikum Region Hannover; A. Schramm, Klinikum Darmstadt; A. Schröder, Medizinische Klinik I Lemgo; J. Schröder, Klinikum Reinkenheide Bremerhaven; H. Schulze-Steinen, Universitätsklinikum Aachen; T. Schumacher, Klinikum Kemperhof Koblenz; K. Schwabe, Gesundheitszentrum Bitterfeld/Wolfen; G. Seifert, Klinikum Kaufbeuren-Ostallgäu Kaufbeuren; J. Soukup, Martin-Luther-Universität Halle-Wittenberg; G. Spalding, Herzzentrum Brandenburg Bernau; T. Standl, Städtisches Klinikum Solingen; W. Steurer, Westpfalz-Klinikum Kaiserslautern; S. Suttner, Gesellschaft für Klinische Forschung Ludwigshafen; W. Szafarczyk-Kuhl, St. Hedwig Kliniken Berlin; H. Tiedau, Klinikum Bremen-Nord 
Bremen; K. Tischbirek, Asklepiosklinik Paulinenkrankenhaus Wiesbaden; C. Träder, Vivantes Auguste-Viktoria-Klinkum Berlin; T. Treu, Müritz-Klinikum Waren; S. Turinsky, Elisabeth-Krankenhaus Essen; T. Uhlig, Klinikum Lüdenscheid; S. Utzolino, Universitätsklinikum Freiburg; D. Volkert, Waldkrankenhaus Rudolf Elle Eisenberg; M. von der Brelie, Universitätsklinikum Schleswig-Holstein Campus Kiel; H. Weigt, Klinikum am Plattenwald Bad Friedrichshall; D. Weiland, Werner-Forssmann-Krankenhaus Eberswalde; G. Weiss, Städtisches Klinikum Magdeburg; K. Wendt, Evangelisch-Freikirchliches Krankenhaus Rüdersdorf; U. Werfel, Klinikum Mitte Essen; S. Wittmann, Klinikum der Universität Regensburg; F. Wolffgramm, Klinikum Mitte Bremen; F. Ziegler, Caritasklinik St. Theresia Saarbrücken; C. Zimmer, Marienhospital Bottrop; H. Zühlke, Evangelisches Krankenhaus Paul-Gerhardt-Stift Wittenberg; M. Zunner, Klinikum Neumarkt, G. Zuz, St. Elisabeth-Krankenhaus Leipzig.

Conflict of interest This study was supported by Wyeth Pharma AG, Muenster, Germany, (now Pfizer Pharma GmbH, Berlin). CE, WRH, and KFB were clinical investigators for Wyeth Pharma GmbH. $\mathrm{CvE}, \mathrm{PAL}$, and $\mathrm{CP}$ are employees of Pfizer Pharma $\mathrm{GmbH}$. CE has received payment from the following companies: Pfizer, Bayer Health Care, Novartis, Astra Zeneca and Durata. WRH has received payments from Bayer and Pfizer. KFB has received payments from Bayer, Pfizer, Astellas, Infectopharm, MSD, and AstraZeneca.

Open Access This article is distributed under the terms of the Creative Commons Attribution License which permits any use, distribution, and reproduction in any medium, provided the original author(s) and the source are credited.

\section{References}

1. Nicolau DP. Management of complicated infections in the era of antimicrobial resistance: the role of tigecycline. Expert Opin Pharmacother. 2009;10:1213-22.

2. Seifert H, Dowzicky MJ. A longitudinal analysis of antimicrobial susceptibility in clinical institutions in Germany as part of the Tigecycline evaluation and surveillance trial (2004-2007). Chemotherapy. 2009;55:241-52.

3. Kresken M, Leitner E, Brauers J, Geiss HK, Halle E, von Eiff C, Peters G, Seifert H. German tigecycline evaluation surveillance trial study group. Susceptibility of common aerobic pathogens to tigecycline: results of a surveillance study in Germany. Eur J Clin Microbiol Infect Dis. 2009;28:83-90.

4. Kresken M, Leitner E, Seifert H, Peters G, von Eiff C. Susceptibility of clinical isolates of frequently encountered bacterial species to tigecycline 1 year after the introduction of this new class of antibiotics: results of the second multicentre surveillance trial in Germany (G-TEST II, 2007). Eur J Clin Microbiol Infect Dis. 2009;28:1007-11.
5. Summary of product characteristics; tigecycline $\left(\right.$ Tygacil $\left.^{\circledR}\right)$; FDA 2013.

6. Summary of product characteristics; tigecycline $\left(\right.$ Tygacil $\left.^{\circledR}\right)$; EMA 2013.

7. Babinchak T, Ellis-Grosse E, Dartois N, Rose GM, Loh E. Tigecycline 301 Study Group; Tigecycline 306 Study Group. The efficacy and safety of tigecycline for the treatment of complicated intra-abdominal infections: analysis of pooled clinical trial data. Clin Infect Dis. 2005;41(Suppl 5):S354-67.

8. Ellis-Grosse EJ, Babinchak T, Dartois N, Rose G, Loh E. Tigecycline 300 cSSSI Study Group; Tigecycline 305 cSSSI Study Group. The efficacy and safety of tigecycline in the treatment of skin and skin-structure infections: results of 2 double-blind phase 3 comparison studies with vancomycin-aztreonam. Clin Infect Dis. 2005;41(Suppl 5):S341-53.

9. Bassetti M, Nicolini L, Repetto E, Righi E, Del Bono V, Viscoli C. Tigecycline use in serious nosocomial infections:a drug use evaluation. BMC Infect Dis. 2010;10:287.

10. Lode HM, Stahlmann R, Kresken M. Multiresistant pathogens-a challenge for clinicians. Zentralbl Chir. 2013;138:549-53.

11. Kujath P, Kujath C. Complicated skin, skin structure and soft tissue infections-are we threatened by multi-resistant pathogens? Eur J Med Res. 2010;15:544-53.

12. Ambrosch A, Haefner S, Jude E, Lobmann R. Diabetic foot infections: microbiological aspects, current and future antibiotic therapy focusing on methicillin-resistant Staphylococcus aureus. Int Wound J. 2011;8:567-77.

13. Meyer E, Schwab F, Gastmeier P. Nosocomial methicillin resistant Staphylococcus aureus pneumonia-epidemiology and trends based on data of a network of 586 German ICUs (2005-2009). Eur J Med Res. 2010;15:514-24.

14. Rubinstein E, Keynan Y. Vancomycin-resistant enterococci. Crit Care Clin. 2013;29:841-52.

15. Bodmann KF, Heizmann WR, von Eiff C, Petrik C, Löschmann PA, Eckmann C. Therapy of 1,025 severely ill patients with complicated infections in a German multicenter study: safety profile and efficacy of tigecycline in different treatment modalities. Chemotherapy. 2012;58:282-94.

16. Ramirez J, et al. Randomized phase 2 trial to evaluate the clinical efficacy of two high-dosage tigecycline regimens versus imipenem-cilastatin for treatment of hospital-acquired pneumonia. Antimicrob Agents Chemother. 2013;57:1756-62.

17. Heizmann P, Lode H, Heizmann WR. Is monotherapy with betalactam antibiotics still up to date? New aspects for treatment of severe infections. Dtsch Med Wochenschr. 2012;137:267-70.

18. Zimmermann JB, Horscht JJ, Weigand MA, Bruckner T, Martin EO, Hoppe-Tichy T, Swoboda S. Patients enrolled in randomised clinical trials are not representative of critically ill patients in clinical practice: observational study focus on tigecycline. Int $\mathbf{J}$ Antimicrob Agents. 2013;42:436-42. 